\title{
Universiteit
}

Leiden

The Netherlands

\section{Loop-directed mutagenesis converts amicyanin from Thiobacillus versutus into a novel blue copper protein}

Dennison, C.; Vijgenboom, E.; Hagen, W.R.; Canters, G.W.

\section{Citation}

Dennison, C., Vijgenboom, E., Hagen, W. R., \& Canters, G. W. (1996). Loop-directed mutagenesis converts amicyanin from Thiobacillus versutus into a novel blue copper protein. Journal Of The American Chemical Society, 118(31), 7406-7407. doi:10.1021/ja953256r

Version: $\quad$ Publisher's Version

License: $\quad$ Licensed under Article 25fa Copyright Act/Law (Amendment Taverne)

Downloaded from: https://hdl.handle.net/1887/3239422

Note: To cite this publication please use the final published version (if applicable). 


\section{Loop-Directed Mutagenesis Converts Amicyanin from Thiobacillus versutus into a Novel Blue Copper Protein}

Christopher Dennison, ${ }^{1 \mathrm{a}}$ Erik Vijgenboom, ${ }^{1 \mathrm{a}}$ Wilfred R. Hagen, ${ }^{1 b}$ and Gerard W. Canters*,1a

\section{Leiden Institute of Chemistry \\ Gorlaeus Laboratories, Einsteinweg 55 P.O. Box 9502, 2300 RA Leiden, The Netherlands}

Received September 25, 1995

Extensive structural, ${ }^{1}$ spectroscopic, and mechanistic studies have shown that small blue copper proteins can be divided into a number of distinctive subclasses..$^{2-5}$ Although the descriptive features of these subclasses are clear-cut, the structural principles underlying this division are less clear. A characteristic trait of all blue copper proteins is that three of the four ligands of the copper atom in the active site are located on a single loop (see Figure 1). It appears that the structure and length of this loop, in part, distinguish the various subclasses. ${ }^{6}$

Recently, site-directed mutagenesis has been applied as a new tool for investigating the peculiarities of blue copper sites. In particular, the effect of point mutations in the coordination sphere of the copper have been investigated in detail. ${ }^{7} \mathrm{We}$ thought it worthwhile to test the above mentioned hypothesis and to study the effect that the ligand loop may have on the copper site by exchanging whole ligand loops between blue copper proteins. This "loop-directed mutagenesis" technique has been applied in the present work to exchange the ligand loop in amicyanin from Thiobacillus versutus with the corresponding loop of plastocyanin from poplar leaves (see Table 1). We obtain a completely viable new blue copper protein with a $\mathrm{Cu}^{2+}$ site that exhibits a striking resemblance to that of a pseudoazurin.

Residues 93-99 comprising the ligand loop in amicyanin were replaced by the corresponding loop of plastocyanin (see Table 1), extending in the process the length of the loop between the ligating His and Met by two residues. The genetic construct was implemented via a plasmid called $\mathrm{pCD} 5,{ }^{8}$ and the corresponding amicyanin variant is called $\mathrm{CD} 5,{ }^{9}$ accordingly. The newly obtained protein exhibits spectroscopic and mechanistic features that clearly distinguish it from the wild-type (wt) amicyanin. The UV-Vis spectrum of the CD5 protein (Figure 2) exhibits a strongly enhanced absorption around $460 \mathrm{~nm},{ }^{10}$ and the EPR spectrum (Figure 2) has conspicuously rhombic features and drastically altered parameters (wt, $g_{z}=2.239, A_{z}$

* Phone: 31071 274256. Fax: 31071 274349. E-mail: CANTERS@ Rulgca.LeidenUniv.nl.

(1) (a) Leiden Institute of Chemistry. (b) Department of Biochemistry, Wageningen Agricultural University, Dreijenlaan 3, 6703 HA Wageningen, The Netherlands.

(2) Sykes, A. G. Adv. Inorg. Chem. 1991, 36, 377-408.

(3) Solomon, E. I.; Baldwin, M. J.; Lowery, M. D. Chem. Rev. 1992 $92,521-542$

(4) Adman, E. T. Adv. Protein Chem. 1991, 42, 144-197.

(5) Chapman, S. K. In Perspectives on Bioinorganic Chemistry; Hay, R. W., Dilworth, J. R., Nolan, K. B., Eds.; Jai Press Ltd.: London, 1991; pp 95-140.

(6) Dennison, C.; Kohzuma, T.; McFarlane, W.; Suzuki, S.; Sykes, A. G. Inorg. Chem. 1994, 33, 3299-3305.

(7) Canters, G. W.; Gilardi, G. FEBS Lett. 1993, 325, 39-48.

(8) The amino acid sequence from His96 to Met99 in wild-type amicyanin was replaced with the sequence His-Gln-Gly-Ala-Gly-Met as found in poplar plastocyanin (see Table 1) using a modified version of the unique-site elimination mutagenesis protocol (Deng, W. P.; Nickoloff, J. A. Anal. Biochem. 1992, 260, 81-88). The mutation was verified by sequencing pCD5.

(9) Expression, isolation, and purification of CD5 were carried out as for the wild-type protein (Kalverda, A. P.; Wymenga, S. S.; Lommen, A.; Van de Ven, F. J. M.; Hilbers, C. W.; Canters, G. W. J. Mol. Biol. 1994, $240,358-371$ ) except that an additional purification step, involving a mono-Q column (FPLC) at $\mathrm{pH} 7.5$, was introduced.

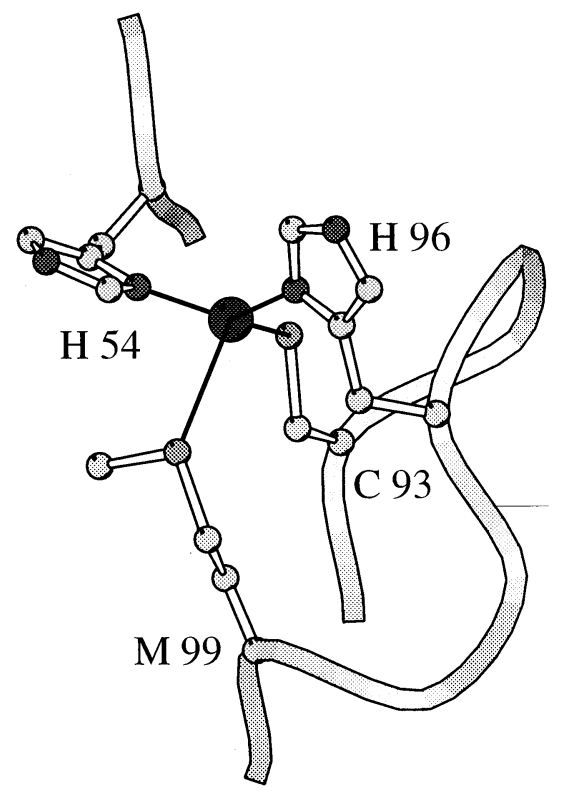

Figure 1. Representation of the $\mathrm{Cu}$-site of amicyanin, showing the loop which contains the three copper ligands Cys93, His96, and Met99. The copper atom is indicated by the dark sphere in the center of the figure.

Table 1. The Amino Acid Sequences of the C-terminal Ligand Containing Loop of Amicyanin from T. versutus, Poplar Plastocyanin, and Pseudoazurin from Alcaligenes faecalis S-6 ${ }^{a}$

Protein Amino-acid Sequence

\begin{tabular}{|c|c|c|c|c|c|c|c|c|c|}
\hline Amicyanin & Cys & Thr & Pro & His & Pro & - & - & Phe & Met \\
\hline & 84 & & & 87 & & & & & 92 \\
\hline \multirow[t]{2}{*}{ Plastocyanin } & Cys & Ser & Pro & His & Gln & Gly & $\mathrm{Ala}$ & Gly & Met \\
\hline & 78 & & & $\$ 1$ & & & & & \\
\hline seudoazurin & Cys & Thr & Pro & His & Tyr & Ala & Met & Gly & Met \\
\hline
\end{tabular}

${ }^{a}$ In all cases the three ligands to the copper are numbered.

$=5.29 \mathrm{mT}, g_{\perp}=2.049 ; \mathrm{CD} 5, g_{z}=2.204, A_{z}=4.3 \mathrm{mT}, g_{y}=$ 2.041, $\left.g_{x}=2.017, A_{x}=6.9 \mathrm{mT}\right) .{ }^{11}$ Both observations point to an enhanced interaction of the "axial" ligand (methionine) with the copper. ${ }^{12-15}$ This is nicely confirmed by a recent NMR study of the paramagnetic copper forms of the wt and CD5 proteins, which indicates a 2 -fold increase in the spin density on the methionine in the CD5 variant. ${ }^{16}$ Additional verification of a shorter $\mathrm{Cu}-\mathrm{S}(\mathrm{Met})$ bond in the CD5 mutant has been obtained from resonance Raman studies which demonstrated that the $\mathrm{Cu}-\mathrm{S}(\mathrm{Cys})$ bond length has increased in comparison to that of the wt protein. ${ }^{17}$

(10) Wild-type amicyanin has a visible absorption band at $596 \mathrm{~nm}(\epsilon$ $\left.3900 \mathrm{M}^{-1} \mathrm{~cm}^{-1}\right)$ and a shoulder at approximately $460 \mathrm{~nm}\left(A_{460} / A_{596}=\right.$ $0.10)$, whereas the CD5 mutant has a main visible band which has shifted to $592 \mathrm{~nm}\left(\epsilon 3900 \mathrm{M}^{-1} \mathrm{~cm}^{-1}\right)$ and a band at $460 \mathrm{~nm}\left(\epsilon 1000 \mathrm{M}^{-1} \mathrm{~cm}^{-1}\right)$, resulting in a $A_{460} / A_{592}$ ratio of 0.26 . The molar absorptivity values for CD5 amicyanin were determined from a titration $\left(25^{\circ} \mathrm{C}\right)$ of the reduced protein with $\left[\mathrm{Fe}(\mathrm{CN})_{6}\right]^{3-}$ at $\mathrm{pH} 7.0$ in $100 \mathrm{mM}$ phosphate buffer (for the titration procedure, see: van de Kamp, M.; Silvestrini, M. C.; Brunori, M.; van Beeumen, J.; Hali, F. C.; Canters, G. W. Eur. J. Biochem. 1990, 194, 109118).

(11) The EPR parameters for CD5 amicyanin were obtained from simulations.

(12) Han, J.; Loehr, T. M.; Lu, Y.; Valentine, J. S.; Averill, B. A.; Sanders-Loehr, J. J. Am. Chem. Soc. 1993, 115, 4256-4263.

(13) Lu, Y.; LaCroix, L. B.; Lowery, M. D.; Solomon, E. I.; Bender, C. J.; Peisach, J.; Roe, J. A.; Gralla, E. B.; Valentine, J. S. J. Am. Chem. Soc. 1993, 115, 5907-5918.

(14) Romero, A.; Hoitink, C. W. G.; Nar, H.; Huber, R.; Messerschmidt, A.; Canters, G. W. J. Mol. Biol. 1993, 229, 1007-1021.

(15) Karlsson, B. G.; Nordling, M.; Pascher, T.; Tsai, L. C.; Sjölin, L.; Lundberg, L. G. Protein Eng. 1991, 4, 343-349.

(16) Kalverda, A. P.; Salgado, J.; Dennison, C.; Canters, G. W. Biochemistry 1996, 35, 3085-3092. 

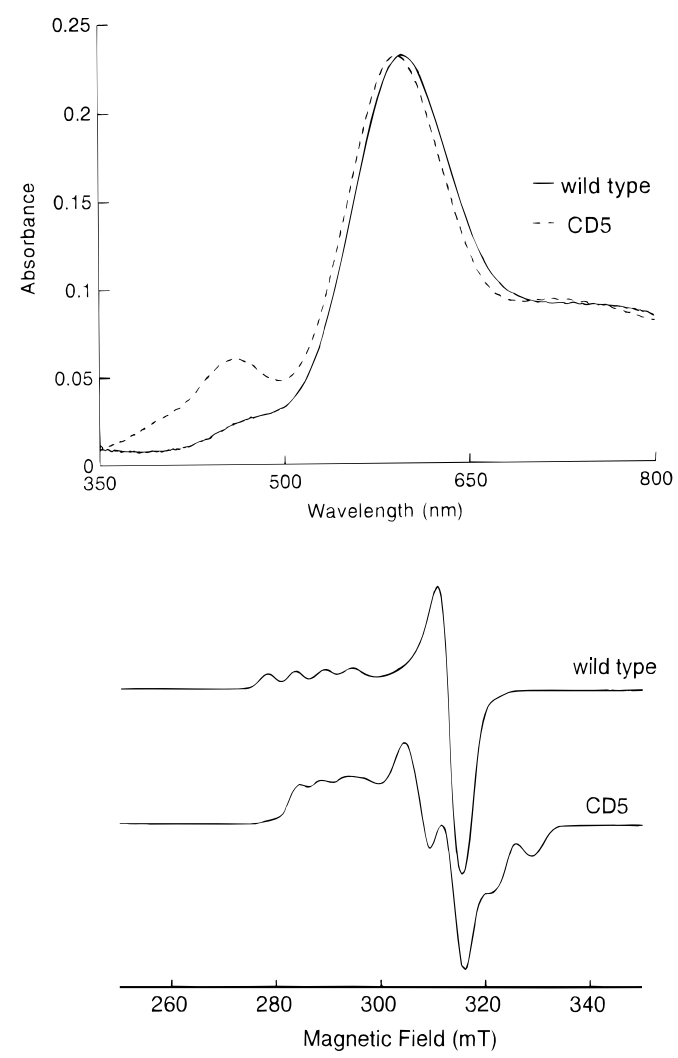

Figure 2. Visible spectra $(298 \mathrm{~K})$ in $50 \mathrm{mM}$ HEPES buffer at $\mathrm{pH} 7.0$ and the X-band $(8.98 \mathrm{GHz})$ EPR spectra $(77 \mathrm{~K})$ in $50 \mathrm{mM}$ HEPES buffer (plus an equal volume of $87 \%$ glycerol) at $\mathrm{pH} 7.0$ of wild-type and the CD5 mutant of amicyanin.

Mechanistic properties have been studied by comparing the electron self-exchange (ese) rate constants as determined by NMR, and the reduction potentials $\left(E^{\circ}\right)$ of $\mathrm{wt}$ and $\mathrm{CD} 5$ proteins. The ese rate constant $\left(25^{\circ} \mathrm{C}\right)$ of the $\mathrm{CD} 5$ protein is about 6 -fold lower than that of $\mathrm{wt}^{18}$ (wt, $1.2 \times 10^{5} \mathrm{M}^{-1} \mathrm{~s}^{-1}$; CD5, $2.1 \times$ $10^{4} \mathrm{M}^{-1} \mathrm{~s}^{-1}$; both determined at $\mathrm{pH}^{*} 8.1$ ( $\mathrm{pH}$ reading not adjusted for the deuterium isotope effect), $I=0.05 \mathrm{M}$ ). The drop in rate is equivalent to an increase in the reorganizational energy of $18 \mathrm{~kJ} / \mathrm{mol}(185 \mathrm{mV})$, an increase in distance between the redox centres in the encounter complex by ca. $1 \AA$, or a 6-fold decrease in the formation constant of the encounter complex. We have to await further structural information to decide which (combination) of these factors is responsible for the observed decrease in rate.

The midpoint potential ${ }^{19}$ of the wt protein depends on $\mathrm{pH}$ (see Figure 3 ) and, when fitted with eq 1 , titrates with a $\mathrm{p} K_{\mathrm{a}}$ red of 6.6. It is known that the $\mathrm{pH}$ dependence is caused by the titration of His96, which at low $\mathrm{pH}$ dissociates from the $\mathrm{Cu}$ when the protein is in the reduced form, thereby rendering the $\mathrm{Cu}$ three-coordinate. ${ }^{18}$ This change from four- to threecoordinate stabilizes the $\mathrm{Cu}^{1+}$ over the $\mathrm{Cu}^{2+}$ form, and an increase in $E^{\circ}$ is observed. The loop replacement causes an increase in the midpoint potential ${ }^{19}$ of $64 \mathrm{mV}$ at $\mathrm{pH} 8.5$ (see

(17) Ai, J.; Dennison, C.; Canters, G. W.; Sanders-Loehr, J. Unpublished results. See: Andrew, C. R.; Yeom, H.; Valentine, J. S.; Karlsson, B. G.; Bonander, N.; van Pouderoyen, G.; Canters, G. W.; Loehr, T.; SandersLoehr, J. J. Am. Chem. Soc. 1994, 116, 11489-11498.

(18) Lommen, A.; Canters, G. W. J. Biol. Chem. 1990, 265, 2768-2774.

(19) The reduction potential was measured as a function of $\mathrm{pH}$ using cyclic voltammetry with the measurements carried out using the apparatus and procedures as described in: Hagen, W. R. Eur. J. Biochem. 1989, 182, $523-530$.

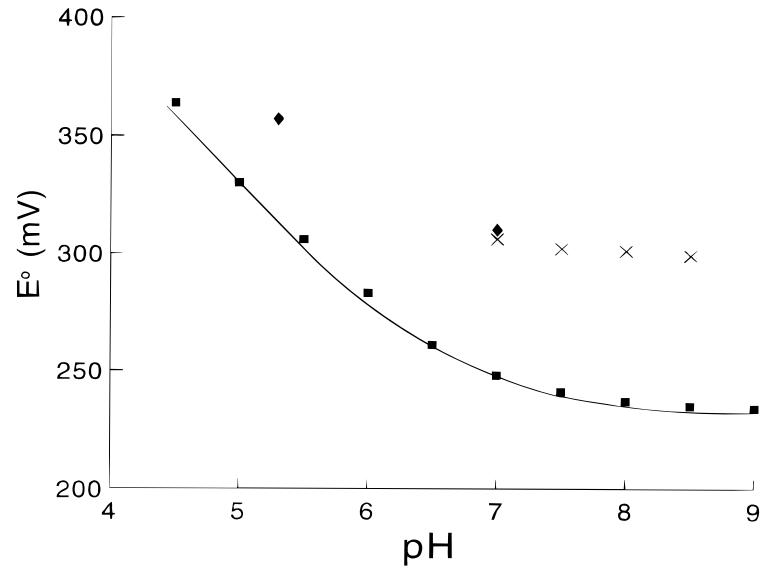

Figure 3. Variation in the reduction potential $\left(E^{\circ}\right)$ with $\mathrm{pH}(I=0.10$ $\mathrm{M}, \mathrm{NaCl}$ ) of wild-type $(\mathbf{\square})$ and the CD5 mutant $(\times)$ of amicyanin. All of the values are referrenced to the NHE at $22{ }^{\circ} \mathrm{C}$, and the line shown for the wild-type data is the fit to eq 1 . Values obtained from titrations of the $\mathrm{CD} 5$ mutant with $\left[\mathrm{Fe}(\mathrm{CN})_{6}\right]^{3-}$ (see refs 20 and 21) are also shown $(\diamond)$.

Figure 3). Moreover, the $\mathrm{p} K_{\mathrm{a}}$ for the titrateable histidine has dropped in CD5 (see Figure 3). ${ }^{20,21}$ The dissociation of the ligand histidine could be observed in the CD5 variant by monitoring the chemical shifts of its $\mathrm{C}^{\delta 2}$ and $\mathrm{C}^{\epsilon 1}$ protons as a function of $\mathrm{pH}$. They titrate with a $\mathrm{p} K_{\mathrm{a}}$ of 5.7. ${ }^{22}$

$$
E^{\circ}(\mathrm{pH})=E^{\circ}(\text { high } \mathrm{pH})+\frac{R T}{n F} \ln \left(1+\frac{\left[\mathrm{H}^{+}\right]}{K_{\mathrm{a}}^{\mathrm{red}}}\right)
$$

The conclusion from this work is that the loop replacement has resulted in a stable, perfectly redox competent protein. Its spectroscopic features resemble neither those of amicyanin nor those of plastocyanin but instead show a striking similarity with the features as published for pseudoazurin (not reproduced). ${ }^{23,24}$ While the lengths of the ligand loops of plastocyanin and pseudoazurin are similar (see Table 1), clearly this length, as the present example shows, cannot be the only feature that determines the active site characteristics. Further loop exchange experiments, dealing with among others the azurins, are in progress.

\section{JA953256R}

(20) The peak separation in the cyclic voltammograms of the CD5 mutant of amicyanin were approximately $100 \mathrm{mV}$ compared to the more ideal value of $60 \mathrm{mV}$ in the case of the wild-type protein. At $\mathrm{pH}$ values below 7.0, the electrochemical response of the CD5 mutant at a bare glassy carbon electrode deteriorated.

(21) Midpoint potentials have also been determined for the CD5 mutant from titrations $\left(25^{\circ} \mathrm{C}\right)$ with $\left[\mathrm{Fe}(\mathrm{CN})_{6}\right]^{3-}$. Values of $310 \mathrm{mV}$ in $100 \mathrm{mM}$ phosphate buffer at $\mathrm{pH} 7.0(I=0.223 \mathrm{M})$ and of $357 \mathrm{mV}$ in $100 \mathrm{mM}$ acetate buffer at $\mathrm{pH} 5.3(I=0.223 \mathrm{M}, \mathrm{NaCl})$ have been determined (see ref 9$)$.

(22) ${ }^{1} \mathrm{H}$ NMR experiments were carried out at $600 \mathrm{MHz}\left(25^{\circ} \mathrm{C}\right)$ with the protein in $20 \mathrm{mM}$ phosphate buffer. The $\mathrm{C}^{\epsilon 1}$ and $\mathrm{C}^{\delta 2}$ protons belonging to the same histidine residue of CD5 amicyanin were identified on the basis of cross peaks between singlets in the aromatic region of a TOCSY spectrum obtained at $\mathrm{pH}^{*} 8.0$ using a relatively long $(70 \mathrm{~ms})$ mixing time. The chemical shift of the resonances of presumably His96 show a large shift with $\mathrm{pH}$ with the $\mathrm{C}^{\epsilon 1} \mathrm{H}$ assigned on the basis of its greater $\mathrm{pH}$ dependence. Due to a $\mathrm{pH}$-induced conformational change at the active site, the resonances of the ring protons of His 54 of CD5 also titrate, but in this case the difference between the resonance frequency in the deprotonated and protonated forms is much less. This is a very similar situation to that found previously for the wild-type protein (see ref 17 and Lommen, A.; Wijmenga, S.; Hilbers, C. W.; Canters, G. W. Eur. J. Biochem. 1991, 201, 695-702.

(23) Suzuki, S.; Sakurai, T.; Shidara, S.; Iwasaki, H. Inorg. Chem. 1989, $28,802-804$.

(24) Dennison, C.; Kohzuma, T.; McFarlane, W.; Suzuki, S.; Sykes, A. G. J. Chem. Soc. Dalton Trans. 1994, 437-443. 